\title{
Sistem Informasi Pengolahan Data Pembelian dan Penjualan Menggunakan Accurate 5SE
}

\author{
Fitri Lydia $^{1}$, Sri Muryani ${ }^{2}$ \\ ${ }^{1}$ Universitas Bina Sarana Informatika \\ e-mail: lydia.fitri10@gmail.com \\ ${ }^{2}$ Sekolah Tinggi Manajemen Informatika dan Komputer Nusa Mandiri \\ e-mail: sri.smy@nusamandiri.ac.id

\begin{tabular}{ccc}
\hline Diterima & Direvisi & Disetujui \\
$23-09-2020$ & $09-11-2020$ & $01-12-2020$ \\
\hline
\end{tabular}

\begin{abstract}
Abstrak - PT. Kabase Indonesia Komoditi merupakan perusahaan dagang di indonesia yang fokus pada pengolahan hasil bumi dan rempah-rempah. Hadir dengan inovasi dan solusi untuk memenuhi kebutuhan konsumennya. PT. Kabase Indonesia Komoditi menawarkan berbagai macam rempah-rempah seperti kacang tanah, kacang hijau, kemiri, ketumbar, bawang putih dan jenis lainnya. PT. Kabase Indonesia Komoditi terus memperluas fokus perusahaan di bidang manufaktur, Tidak hanya membeli bahan baku secara lokal tetapi melalui import pula. Oleh karena itu sangat dibutuhkan sistem komputer untuk memastikan semua data keuangan seperti transaksi-transaksi yang terjadi tidak ada yang terlewatkan dalam pencatatan, sehingga perusahaan dapat mengetahui seberapa besar laba atau ruginya perusahaan setiap periode. Penelitian ini mengenai system pengolahan data keuangan yang berupa pembelian dan penjualan di PT. Kabase Indonesia. Dalam hal ini system pencatatan menggunakan Accurate merupakan solusi awal yang dapat dilakukan dalam memecahkan permasalahan yang ada pada PT. Kabase Indonesia Komoditi, sehingga proses pencatatan akan lebih mudah dari yang sebelumnya. Serta dengan system yang terkomputerisasi, dapat tercapai suatu kegiatan yang lebih efektif dan efesien dalam menunjang kinerja pada perusahaan.
\end{abstract}

Kata Kunci: sistem informasi, pengolahan data penjualan, Accurate 5SE

\begin{abstract}
PT. Kabase Indonesia Komoditi is a trading company in Indonesia that focuses on processing agricultural products and spices. Present with innovations and solutions to meet the needs of its consumers. PT. Kabase Indonesia Komoditi offers various kinds of spices such as peanuts, green beans, candlenuts, coriander, garlic and other types. PT. Kabase Indonesia Komoditi continues to expand the company's focus in manufacturing, not only buying raw materials locally but also through imports. Therefore, a computer system is needed to ensure that all financial data such as transactions that occur are not missed in the recording, so that the company can find out how much profit or loss the company has for each period. This research is about the financial data processing system in the form of buying and selling at PT. Kabase Indonesia. In this case the recording system using Accurate is an initial solution that can be done in solving problems that exist at PT. Kabase Indonesia Komoditi, so that the recording process will be easier than the previous one. And with a computerized system, an activity that is more effective and efficient in supporting the performance of the company can be achieved.
\end{abstract}

Keywords: information systems, sales data processing, Accurate 5SE

\section{PENDAHULUAN}

PT. Kabase Indonesia Komoditi merupakan perusahaan dagang di indonesia yang fokus pada pengolahan hasil bumi dan rempah-rempah. Hadir dengan inovasi dan solusi untuk memenuhi kebutuhan konsumennya. PT. Kabase Indonesia Komoditi menawarkan berbagai macam rempahrempah seperti kacang tanah, kacang hijau, kemiri, ketumbar, bawang putih dan jenis lainnya. PT. Kabase Indonesia Komoditi terus memperluas fokus perusahaan di bidang manufaktur, Tidak hanya membeli bahan baku secara lokal tetapi melalui import pula.

Dalam mengolah data pada PT. Kabase Indonesia Komoditi masih menggunakan cara manual. Inilah salah satu hambatan yang cukup besar dalam kegiatan peningkatan kualitas, serta keakuratan informasi yang diberikan dan nantinya akan dihasilkan oleh suatu perusahaan. Sedangkan pada era saat ini dibutuhkan sarana dan prasarana yang dapat membantu proses pengolahan data denga cepat, tepat dan akurat. Untuk mempermudah dalam mengolah data di PT. Kabase Indonesia Komoditi 
maka penulis akan mencoba menerapkan suatu sistem akuntansi dengan menggunakan aplikasi ACCURATE 5 SE (Standar Edition) karena aplikasi ini userfriendly, sederhana dan sangat mudah dipelajari dan sesuai dengan berbagai jenis usaha.

Dengan adanya penerapan aplikasi ini, diharapkan dapat membantu dan mendukung jalannya suatu system yang berjalan pada PT. Kabase Indonesia Komoditi sehingga memperoleh suatu hasil yang lebih baik.

Untuk memudahkan dan mempercepat tugastugas administratif yang memerlukan ketelitian, keakuratan dan keamanan, maka dibutuhkan software akuntansi sebagai alat .

Software Accurate 5 SE (Standar Edition) adalah pilihan terbaik bagi para pebisnis skala kecil dan menegah. Software Accurate 5 SE (Standar Edition) akan membantu anda menyelesaikan pekerjaan dengan cepat, meskipun anda tidak mengerti dasar-dasar akunting sama sekali. Software Accurate 5 SE (Standar Edition) dirancang dalam dua bahasa (Inggris, Indonesia) dengan tampilan Interface User Friendly yang sangat mudah digunakan, tentunya dengan hasil yang akurat.

Software Accurate 5 SE (Standar Edition) dapat melakukan pencatatan pembukuan seperti transaksi penjualan, pembelian, inventory/stok, penjualan jasa, pecatatan biaya-biaya dsb, serta penyusunan laporan keuangan hanya dalam beberapa langkah mudah serta cepat dan akurat.

Software Accurate 5 SE (Standar Edition) dikembangkan sejak 1999 oleh PT Cipta Piranti Sejahtera (CPSSoft Developer of ACCURATE Software) dan telah diaplikasikan oleh lebih dari 50.000 pengguna dan bekerja sama dengan lebih dari 30 Universitas terkemuka Indonesia sebagai mitra accurate. "Accurate Accounting adalah software yang digunakan untuk mempermudah pengelolaan data keuangan dengan tingkat ketelitian yang tinggi sehingga menghasilkan laporan keuangan, neraca, laba dan rugi lebih cepat." Setelah mengaktifkanaplikasi Accurate akan muncul gambar seperti ini.

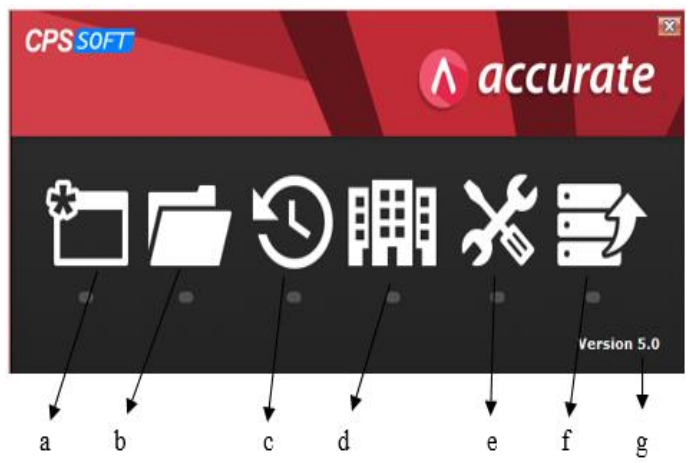

Sumber :Aplikasi Accurate versi 5 SE (2019)

Gambar1. Tampilan Menu Utama Accurate

\section{METODE PENELITIAN}

Metode penelitian yang dilakukan dalam penulisan tugas mata kuliah Sistem Informasi Akuntansi adalah :

a. Peninjauan lapangan (Observasi)

Metode ini dilakukan dengan cara meninjau secara langung kegiatan yang berhubungan dengan sistem penjualan dan pembelian pada PT. Kabase Indonesia Komoditi yang beralamat di Jl. Cipinang Jaya Raya No 48, Jakarta Timur.

b. Wawancara (Interview)

Pengumpulan data dilakukan dengan cara tanya jawab secara langsung dengan salah satu Staff PT. Kabase Indonesia Komoditi yaitu Bapak Juneadi Darma. Diharapkan informasi yang diperoleh benar-benar dapat dipertanggung jawabkan atas pertanyaan yang diajukan.hal ini untuk bahan pertimbangan kearah proses yang ada.

c. Kepustakaan (Library)

Selain dengan pengamatan langsung dan wawancara, peneliti juga melakukan pengumpulan data dengan membaca sumbersumber tertulis yang terdapat dalam buku-buku referensi atau penelitian lain yang sesuai dengan tema penelitian ini.

\section{HASIL DAN PEMBAHASAN \\ Setup Data Awal}

Sebelum membuat Database di Komputer Lokal, pastikan Firebird dan Program ACCURATE di komputer tersebut telah terinstall dengan baik. Berikut ini langkah yang dapat Anda lakukan untuk membuat Database baru di Komputer Lokal (di dalam hard disk PC sendiri).

\section{Membuat Kode Akun}

Berikut langkah-lagkah untuk pembuatan daftar akun :

1. Untuk melihat seluruh daftar akun klik Daftar lalu pilih Daftar Akun dan akan tampil seperti gambar dibawah ini :

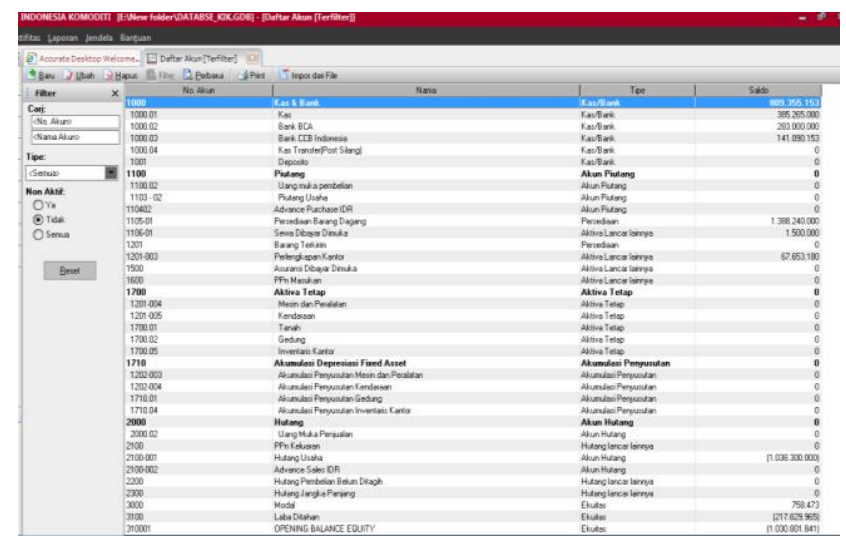

Sumber: Hasil Penelitian (2019)

Gambar 2. Tampilan Daftar Akun 
Daftar Akun adalah Tabel yang menampilkan Daftar Akun-Akun yang Anda miliki. Akun-akun yang terdapat pada Daftar Akun ini nantinya akan ditampilkan sebagai detail dari laporan keuangan.

\section{Membuat Data Customer}

Untuk membuat daftar Tipe Pelanggan dapat Anda lakukan dengan cara:

1. Klik menu utama Daftar - Daftar Lain (List Other List)

2. Lalu pilih Tipe Pelanggan (Customer Type)

3. Pada tabel daftar Tipe Pelanggan, klik tombol New (Baru)

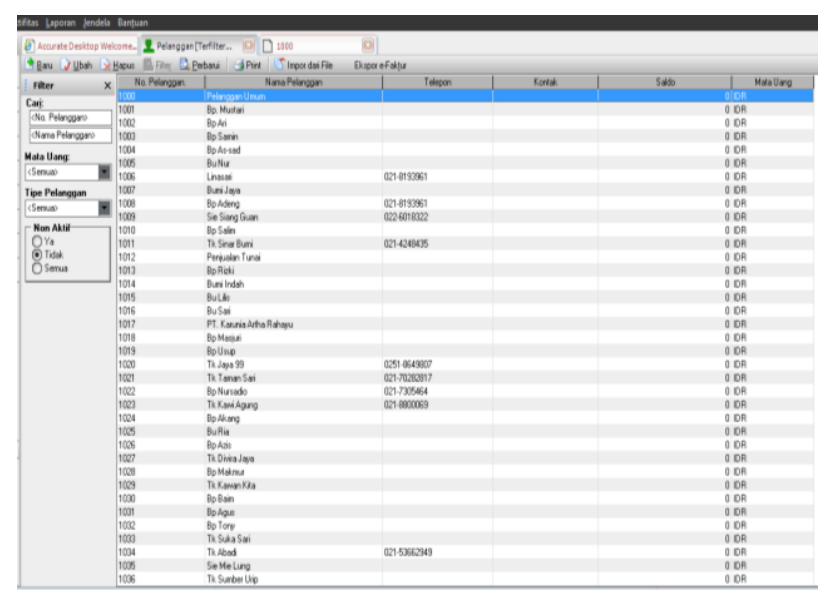

Sumber: Hasil Penelitian (2019)

Gambar 3. Tampilan Daftar Customer

\section{Daftar Barang}

Untuk membuat daftar Barang dapat Anda lakukan dengan cara:

1. Klik menu utama Daftar - Barang dan Jasa

2. Lalu pilih Barang dan Jasa

3. Pada tabel daftar Barang dan Jasa , klik tombol New (Baru)

4. Pada formulir barang dan jasa yang baru, isi barang dan jasa yang anda inginkan.

5. Klik tombol OK untuk menyimpan tipe pelanggan yang baru Anda input.

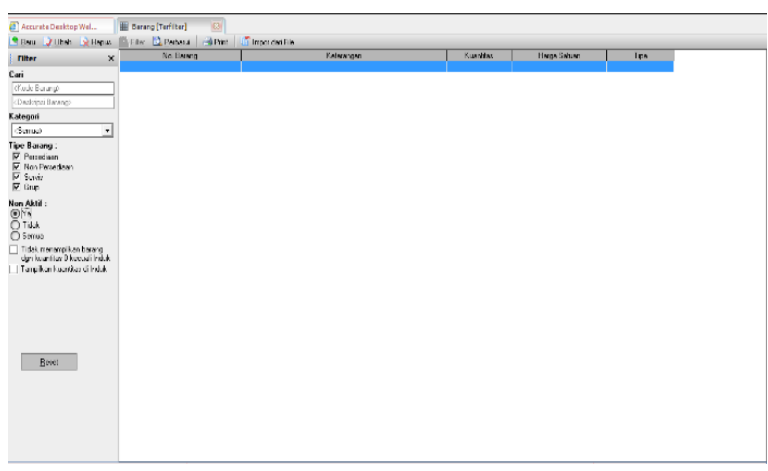

Sumber: Hasil Penelitian (2019)

Gambar 4. Tampilan Daftar Barang dan Jasa

\section{Saldo Awal Akun}

Berikut data saldo awal akun bulan Feb 2019

PT. Kabase Indonesia Komoditi sebagai berikut.

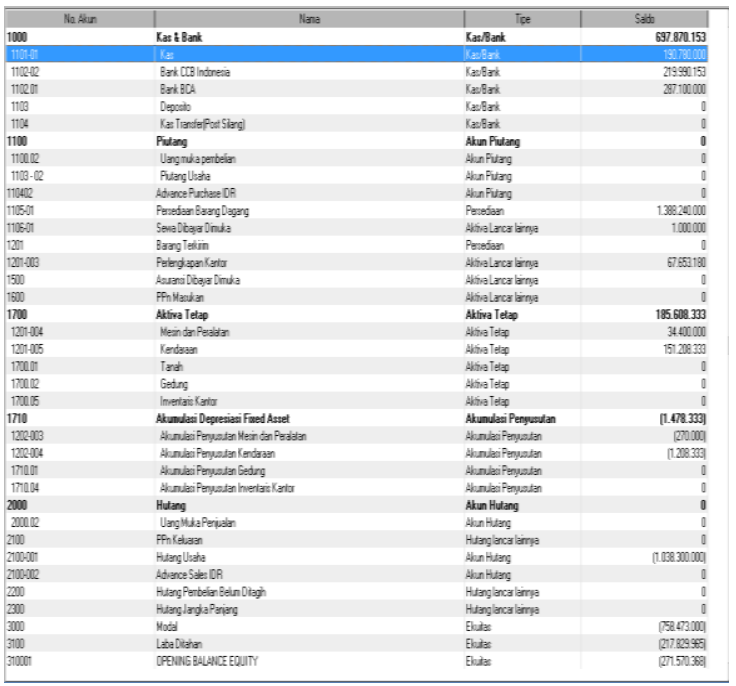

Sumber: Hasil Penelitian (2019)

Gambar 5.Tampilan Saldo Awal

\section{Input Data Transaksi}

Dalam satu bulan, entry data Penjualan yang terjadi pada PT. Kabase Indonesia Komoditi sangat banyak. Berikut adalah sebagian contoh transaksi yang terjadi :

1. 01 Feb 2019 :Penjualan barang KT - 003 (KT 140/160) sebanyak 2 bal seharga @ 890.000,pada Bapak Samin, No Faktur FP-2101 dengan total Rp. 1.780.000,-dibayar secara tunai.

Langkah untuk menyelesaikan atau menginput transaksi diatas kedalam Accurate adala pilih Modul Daftar, Penjualan, Faktur Penjualan, lalu Isi data sesuai dengan transaksi, klik Simpan \& Tutup. Seperti gambar dibawah ini :
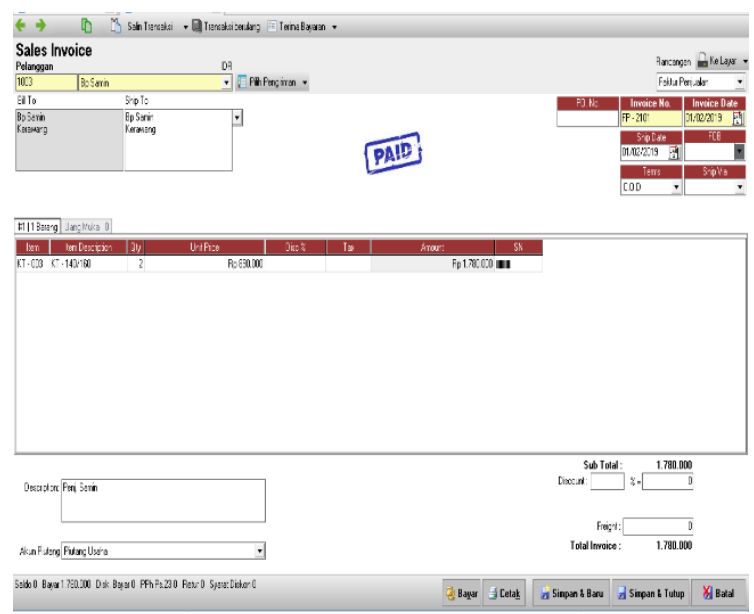

Sumber: Hasil Penelitian (2019)

Gambar 6. Input Data Penjualan 
2. 01 Feb 2019 : Penjualan barang KT - 004 (KT 80/90 TJ) sebanyak 40 bal seharga @915.000,pada Bapak As'sad, No Faktur FP-2102 dengan total Rp. 36.600.000,-dibayar secara tunai.

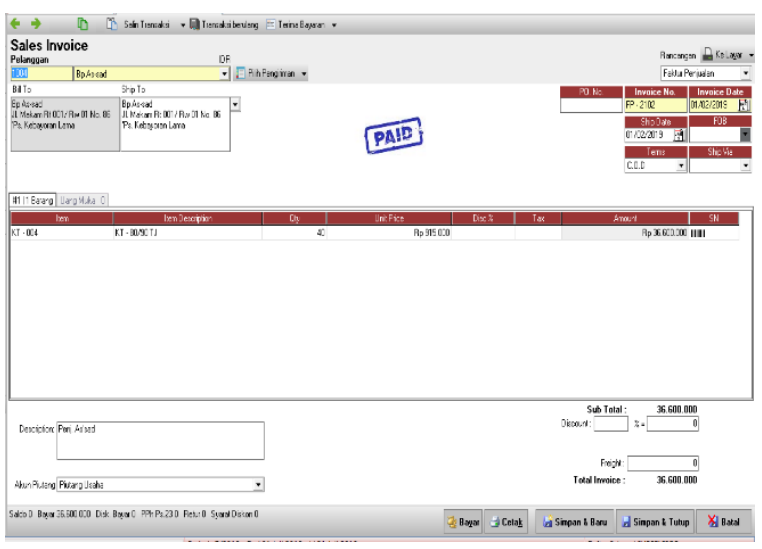

Sumber: Hasil Penelitian (2019)

Gambar 7. Tampilan Menginput Data Penjualan

Bila transaksi dilakukan secara kredit isi kolom syarat pembayarannya jika tidak pilih COD.

Berikut daftar transaksi penjualan pada PT. Kabase Indonesia Komoditi yang terjadi selama bulan Februari 2019 :

\begin{tabular}{|c|c|c|c|c|c|c|c|c|c|c|}
\hline \multicolumn{11}{|c|}{ 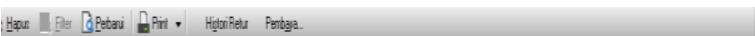 } \\
\hline lofats & | Trogs || & ind |la Petrogyan & \begin{tabular}{|l|} 
Narafergyan | \\
\end{tabular} & 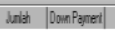 & 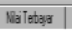 & Didm & FAPR Z2 & Petr & Owing & |etergon A \\
\hline $\mathbb{P P} \cdot 200$ & MFobl9 & 01003 & Bos sin & 17000000 & 1200000 & 0 & 0 & & 0 & OPris Sam \\
\hline $\mathbb{P} \cdot 2 \pi \mathbb{R}^{2}$ & 0 & 01004 & Bopenad & x6000000 0 & 350000 & 0 & 0 & & 0 & 0 Pritiksat \\
\hline $\mathbb{P P} \cdot 210$ & Mofib 19 & 0105 & Bullu & 28000000 & 280000 & 0 & i & & 0 & OPrilly \\
\hline $\mathbb{P} \cdot 204$ & MFat 19 & 01065 & Lressi & 24000000 & 2400000 & 0 & 0 & & 0 & O Prit Lieza \\
\hline $\mathbb{P} \cdot 2115$ & MFabl9 & 01007 & Briba & 67000000 & 2570000 & 0 & i & & 0 & 0 Path PI? \\
\hline $\mathbb{P P} \cdot 2016$ & MFabls & 01008 & Bpoleng & 25000000 & 250000 & 0 & i & & 0 & o preiblat \\
\hline $\mathbb{7} \cdot 200$ & MFeblis & 01009 & Sefirgaban & 124000000 & 1250000 & 0 & 0 & & 0 & o priseses. \\
\hline $\mathbb{P} \cdot 2108$ & Werdis & 0100 & Bpostin & 300000 & 30000 & 0 & 0 & & 0 & Operisin \\
\hline $\mathbb{P} \cdot 2109$ & WFet 19 & 01011 & Tisnablui & 160000000 & 1600000 & 0 & 0 & & 0 & Opris rerat \\
\hline FP. 2210 & WFetis & 01012 & Penisar Turá & 955000 & 95000 & 0 & 0 & & 0 & Opai lura \\
\hline $\mathbb{P P}-2111$ & QRebt19 & 0103 & Bppodi & 18900000 & 1800000 & 0 & 0 & & 0 & OPrifidi \\
\hline $\mathbb{1 1} \cdot 2712$ & WFabl9 & 2104 & Biningh & 178000000 & 1780000 & 0 & i & & 0 & OPribaril \\
\hline $\mathbb{P} \cdot 2213$ & Werbl9 19 & 01015 & Bulis & 4000000 & 420000 & 0 & i & & 0 & o Prilik \\
\hline $\mathbb{P} \cdot 2714$ & MFab 19 & 01065 & Bussi & 500000 & 50500 & 0 & 0 & & 0 & OPrisi \\
\hline $\mathbb{P} \cdot 2115$ & OFFb 19 & 21077 & 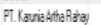 & 8900000 & 890000 & 0 & 0 & & 0 & OPrik:A \\
\hline $\mathbb{P} \cdot 2116$ & Offed 19 & 01018 & Bo kaji & 300000 & 30000 & 0 & i & & 0 & OPgillisis \\
\hline $\mathbb{P} \cdot 2117$ & Wfetis & 01099 & Boluse & 9565000 & 958500 & 0 & 0 & & 0 & o privilap \\
\hline Pf. 27118 & 07Fab 19 & 0100 & Truag & 9400000 & 900000 & 0 & 0 & & 0 & Proikges \\
\hline $\mathbb{P} \cdot 2119$ & OFFeb19 & 0100 & TKTrara Sai & 188000000 & 1800000 & 0 & 0 & & 0 & O Parit Tans \\
\hline $\mathbb{P} \cdot 200$ & WeFt 19 & 0102 & Bollenso & 175000000 & 1780000 & 0 & 0 & & 0 & Operilleras \\
\hline $\mathbb{1 P} \cdot 22 \pi$ & Defat 19 & 01103 & Thlarikgrg & 25400000 & 2500000 & 0 & 0 & & 0 & 0 Path $/ 3$ ai \\
\hline $\mathbb{P} \cdot 272$ & DeFth & 0104 & Bolisy & 800000 & 800000 & 0 & 0 & & 0 & OPrititsg \\
\hline $\mathbb{P} \cdot 2123$ & Dofed19 & 01065 & Bufia & 80000000 & 880000 & 0 & 0 & & 0 & OPrifigi \\
\hline $\mathbb{P P} \cdot 224$ & Wfethl19 & 01265 & Bpozas & 180000000 & 18800000 & 0 & i & & 0 & OPritas \\
\hline $\mathbb{P} \cdot 216$ & 11 Fed 19 & 0107 & Thomalage & 167200000 & 16720000 & 0 & 0 & & 0 & 0 Pri Dima. \\
\hline $\mathbb{P P} \cdot 216$ & 11 Fabl19 & 01108 & Bpoldenu & 75000000 & 750000 & 0 & i & & 0 & o Prillitan \\
\hline 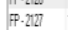 & $12 F+19$ & 01209 & ThKays) & 9200000 & 920000 & 0 & 0 & & 0 & oprikars \\
\hline $\mathbb{P P} \cdot 218$ & 13 Fet 19 & 01000 & $B B \operatorname{Bn}$ & 84000000 & 800000 & 0 & 0 & & 0 & OPribin \\
\hline $\mathbb{P} \cdot 2128$ & $13 \mathrm{Feb} 19$ & -1 1001 & Bpheg & 82550000 & 825500 & 0 & i & & 0 & Ofrikge \\
\hline $\mathbb{P} .2130$ & $13 \mathrm{Feb} 19$ & 0102 & botry & 300000 & 30000 & 0 & 0 & & 0 & opritiong \\
\hline $\mathbb{R} .2277$ & 14 Fib 19 & 01783 & 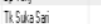 & 95000 & 95000 & 0 & i & & 0 & ofrisisa? \\
\hline $\mathbb{P P}-212$ & 155 bl19 & 0104 & Trabaj & 15500000 & 1650000 & 0 & i & & & OPriflaba \\
\hline 17.2733 & $15 \mathrm{Fb} 19$ & 01055 & Selkelung & 25050000 & $2(501000$ & 0 & i & & 0 & 0 Pant SEk \\
\hline $\mathbb{P P} \cdot 2313$ & 15Fetli & 01005 & ThSinteulip & 178550000 & 17285000 & 0 & i & & 0 & OPris inte \\
\hline $\mathbb{P} \cdot 215.5$ & 155 bil 19 & 01007 & Bplasi & 42000000 & 4200000 & 0 & 0 & & 0 & OPrillatis \\
\hline$P .275$ & $18 F$ bits & 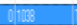 & IT Fra Patso & 880000 & 80000 & Di & 0 & & i & 0 \\
\hline 8 & & & & & & & & & & , \\
\hline
\end{tabular}

Sumber: Hasil Penelitian (2019)

Gambar 7. Daftar Transaksi Penjualan

Dalam satu bulan, entry data Pembayaran Pembelian yang terjadi pada PT. Kabase Indonesia Komoditi adalah sebagai berikut :

1. 08 Feb 2019 : Pembayaran hutang dagang kepada sangam export dengan Invoice No 1111 atas KT -
010 (KT - 140/160) sebesar Rp. 78.000.000,melalui TT di Bank CCB Indonesia.

Langkah untuk menyelesaikan atau menginput transaksi diatas kedalam Accurate :

Pilih Modul Daftar, Pembelian, Pembayaran, Pembelian, Isi data sesuai dengan transaksi lalu klik Simpan \& Tutup. Seperti gambar dibawah ini.

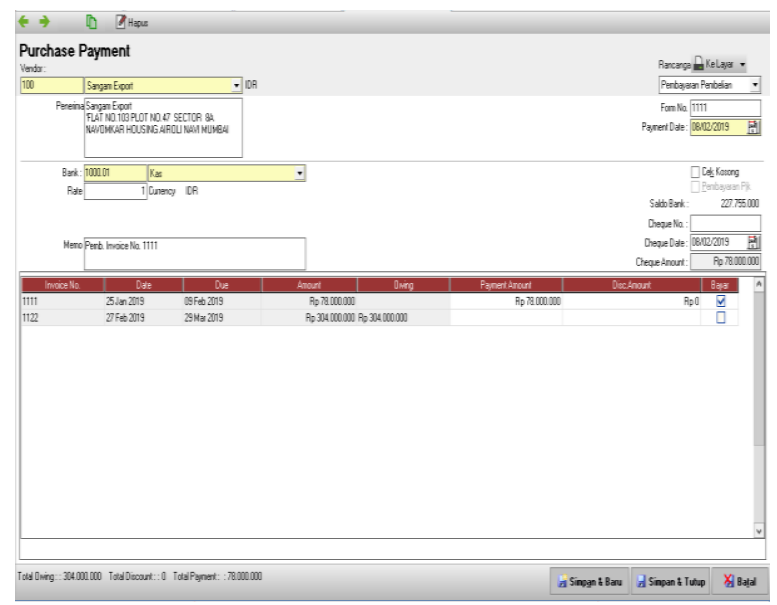

Sumber: Hasil Penelitian (2019)

Gambar 8. Tampilan Menginput Data Pembayaran Pembelian

2. 14 Feb 2019 : Pembayaran Hutang Usaha Invoice No 1112 dibayar secara tunai

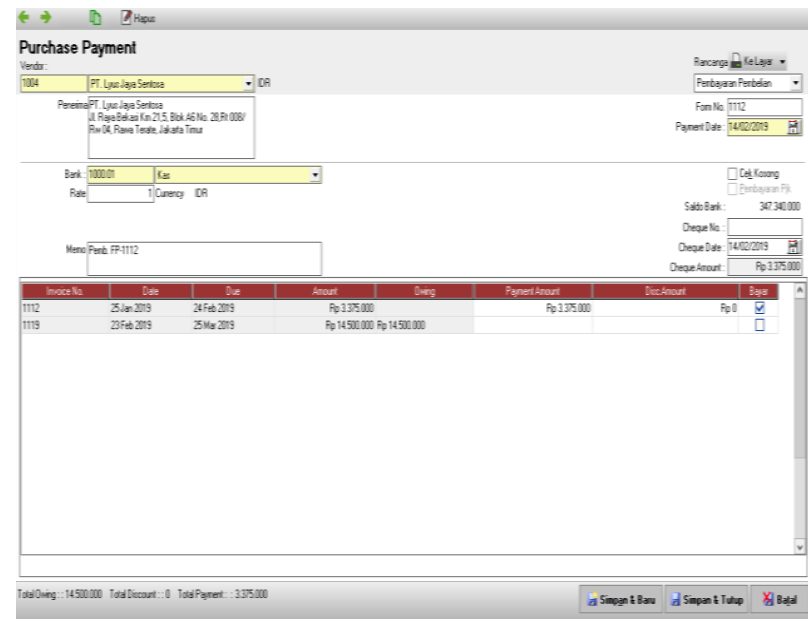

Sumber: Hasil Penelitian (2019)

Gambar 9. Tampilan Menginput Data Pembayaran Pembelian

Berikut daftar transaksi pembayaran pembelian pada PT. Kabase Indonesia Komoditi yang terjadi selama bulan februari 2019 : 


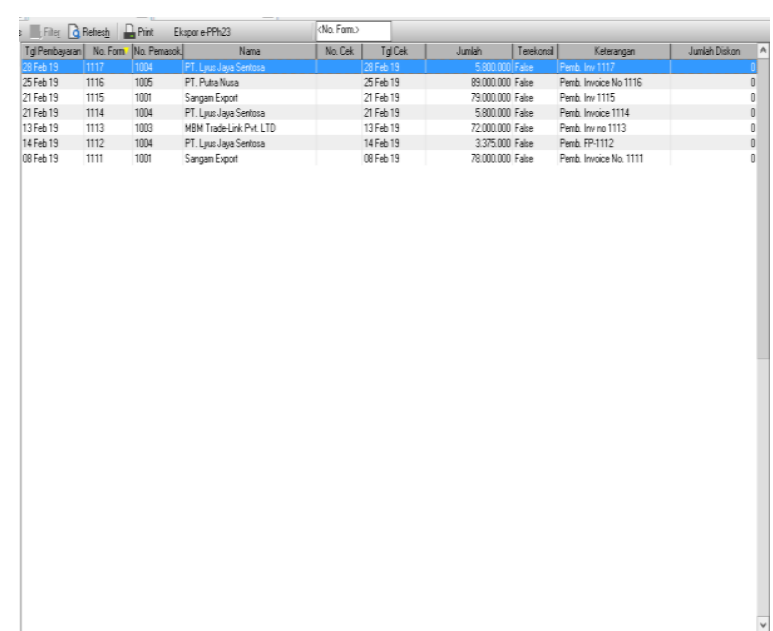

Sumber: Hasil Penelitian (2019)

Gambar 10. Daftar Transaksi Pembayaran Pembelian.

\section{Laporan}

Sesuai dengan data transaksi yang telah diinput dalam Accurate, maka secara otomatis Accurate akan membentuk laporan-laporan keuangan yang dengan mudah dapat user lihat.

Untuk melihat laporan-laporan yang sudah disediakan oleh Accurate maka user hanya tinggal memilih atau mengklik Modul Laporan, akan tampil jendela berbagai laporan keuangan dan user dapat membuka laporan tersebut satu persatu.

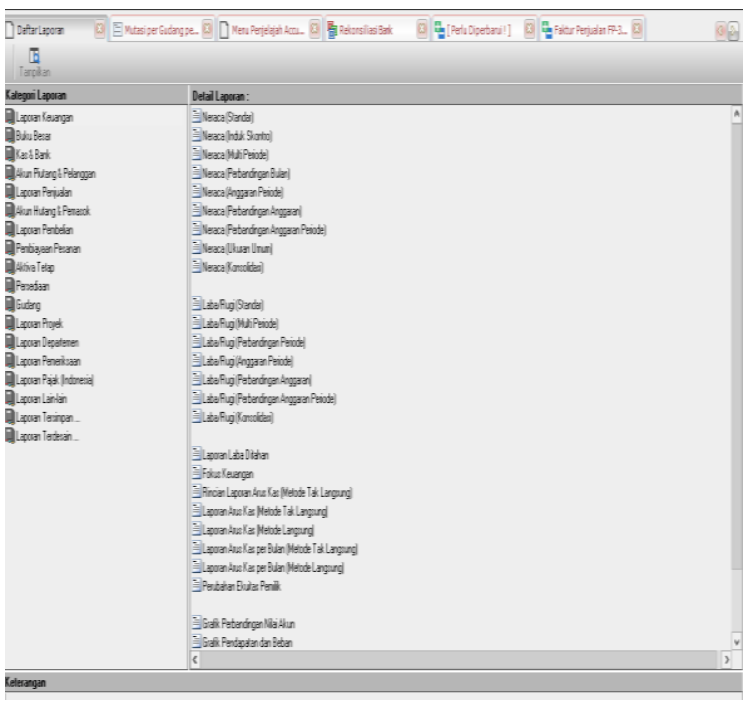

Sumber: Hasil Penelitian (2019)

Gambar 11. Daftar Laporan Keuangan

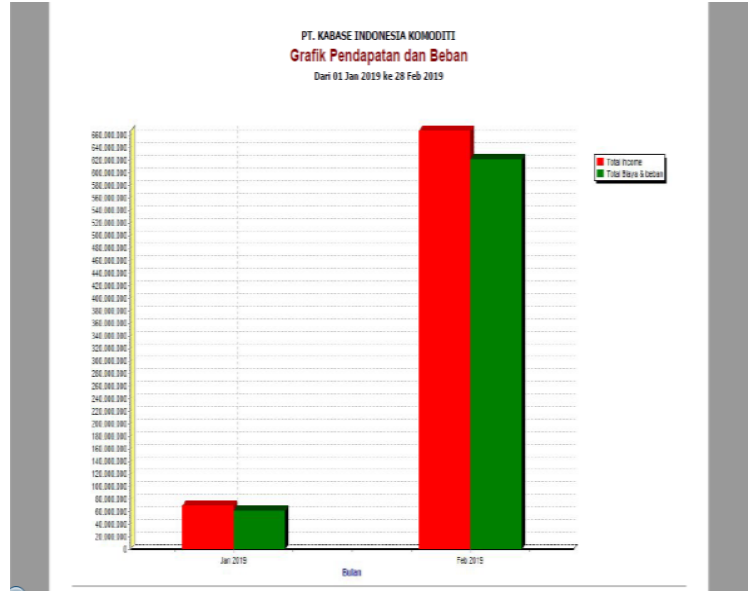

Sumber: Hasil Penelitian (2019)

Gambar 12. Analisa Laporan Keuangan.

\section{KESIMPULAN}

Setelah melalui tahap pembuatan laporan keuangan, akhirnya peneliti dapat menyelesaikan penerapan aplikasi program akuntansi Accurate Accounting mengenai pengolahan data pembelian dan penjualan pada PT. Kabase Indonesia Komoditi.

Kesimpulan dari hasil penelitian ini adalah menggunakan aplikasi program Accurate Accounting 5 Standart Edition dapat mempermudah dalam penginputan transaksi pada PT. Kabase Indonesia Komoditi, karena setiap transaksi akan di input dan dipisahkan sesuai jenis transaksinya seperti penjualan, pembelian, kas masuk dan kas keluar.

Dalam hal menyimpan data dapat menjadi aman dan tersusun secara sistematis hingga nantinya lebih mudah untuk mengarsipkan data atau file dan juga menemukan datanya. Hasilnya dari program aplikasi ini dapat menghasilkan laporan keuangan dengan tepat dan memberikan informasi kepada pemilik perusahaan mengenai aktivitas perusahaannya, sehingga berguna untuk pengambilan keputusan manajemen.

Penggunaan program aplikasi Accurate Accounting Standart Edition dapat memperbaiki sistem standart perusahaan, yang sebelumnya system dalam pembukuan PT. Kabase Indonesia Komoditi dilakukan secara manual menjadi terkomputerisasi sehingga mempermudah dalam pembuatan laporan keuangan pada PT. Kabase Indonesia Komoditi untuk setiap periodenya.

\section{REFERENSI}

Bahri, S. (2016). Pengantar Akuntansi. Yogyakarta: CV. Andi Offset.

Ichsan. (2013, November). Sistem Pendukung Keputusan Pemilihan Penerima Beasiswa Mahasiswa Kurang Mampu Pada STMIK 
BUDIDARMA Medan Menerapkan Metode Profile Matching. Kursor, 5(1), 2.

Kendall, K. d. (2013). Analisis dan Perancangan Sistem. Klaten: PT. Intan Sejati.

Krismiaji. (2015). Sistem Informasi Akuntansi. Yogyakarta: UPP STIM YKPN.

Ladjamudin, A. (2013). Analisis dan Desain Sistem Informasi. Yogyakarta: Graha Ilmu.

Normah. (2018). Implementasi IT Pada Sistem Informasi Akuntansi PT. Master Grafika Jakarta. 4(1)

Nur Majdina Hibatur Rahman, S. M. (2017). Aplikasi Akuntasi Untuk Menyusun Laporan
Keuangan Pada Koperasi Amanah Jakarta. 1(2).

R.A. Sukamto, M. S. (2014). Rekayasa Perangkat Lunak. Bandung.

Rahmawati, M. (2015). Usaha Dalam Perspektif Sistem Informasi. XIII(2).

Tohari, H. (2014). Analisis Serta Perancangan Sistem Informasi Melalui Pendekatan UML. Yogyakarta: Andi. 